\title{
BELÜGYMINISZTÉRIUM ÖNKORMÁNYZATI ÁLLAMTITKÁRSÁGA A MAgYAR ÖNKORMÁNYZATI RENDSZER MODERNIZÁCIÓJA Modernization OF THE Hungarian LOCAL GOVERNMENT SYSTEM
}

A tanulmány alapvetően az önkormányzatok gazdasági-pénzügyi helyzetére, a helyi gazdaságfejlesztés lehetöségeire fókuszál. Ugyanakkor szükségesnek látjuk - a terjedelmi korlátokra is tekintettel - az önkormányzati szervezetrendszer átalakulásának, egyes elemeinek, új jogintézményeinek bemutatását. Minden részletre természetesen nem áll módunkban kitérni, de talán az Olvasó számára is hasznos ismereteket közvetíthetünk az önkormányzatok müködéséröl.

This study aims to present the economic, financial situation and possible economic development of local governments. However, for reasons of space, we considered necessary to present the new elements and legal institutions of transforming local government bodies. Our paper, of course, cannot intend to cover every aspect of the topic, but we hope to share useful knowledge to the reader on local governments.

\section{A HELYI ÖNKORMÁNYZATOK RENDSZERÉNEK MEGÚJÍTÁSA}

\section{Az ELŐZMÉNYEK}

Hazánkban az önkormányzati rendszer kialakításakor a helyi önkormányzatok meghatározó szerepet kaptak a közszolgáltatások biztosításában.

Ennek egyik fontos oka az volt, hogy a rendszerváltoztatás szakított a „mindenható állam” eszményképével, a közfeladatok ellátásában esetenként a szükségesnél nagyobb mértékben minimalizálta az állam szerepét. A civil szervezetek, az egyházak pedig még nem voltak elég erősek ahhoz, hogy az európai trendeknek megfelelő arányban vegyék ki részüket a lakossági közszolgáltatások biztosításából. Az is cél volt, hogy nagy önállósággal rendelkező, erős önkormányzati rendszert alakítsunk ki, ez pedig széles feladat- és hatásköri struktúrát feltételezett, amely azonban a kezdetektől fogva ellentmondásban állt a szétaprózódott településszerkezettel, és hosszabb távon hozzájárult az önkormányzati működés elnehezüléséhez és megoldást igényelt.

\section{A Fő JELLEMZÖK}

A 2010-ben elindított önkormányzati reform több tekintetben különbözött a korábbi időszakok korszerüsítési törekvéseitől.

Egyrészt a helyi önkormányzatok rendszerét az államszerkezet átalakításának részeként, azzal összhangban kívánta átalakítani, célzottan az állam szerepvállalásának újragondolásával együtt. Másrészt figyelembe vette azt, hogy az önkormányzati rendszer müködési zavarainak jó 
része a helyi önkormányzatok által ellátott ágazati feladatokat kísérő anomáliákból származott, így a megújítás elképzelhetetlen sikeres ágazati reformok nélkül.

Alapvető célként került rögzítésre, hogy e folyamatban a Magyarország helyi önkormányzatairól szóló 2011. évi CLXXXIX. törvénynek (Mötv.) az az elsődleges rendeltetése, hogy az elodázhatatlan ágazati reformok számára megfelelő feladat-telepítési és feladat-ellátási elveket, kereteket biztosítson, alkalmassá téve az önkormányzati rendszert a megújult struktúrák befogadására.

Az Mötv. a magyar önkormányzati hagyományokra építve, figyelembe véve az Európai Önkormányzati Charta elveit, azokat összhangba hozva a hazai sajátosságokkal meghatározta a helyi önkormányzás alapvető fogalmi elemeit, megnevezte alanyát, tárgyát, tartalmát.

A törvény értelmében települési önkormányzatok a községekben, a városokban, a járásszékhely városokban, a megyei jogú városokban és a fövárosi kerületekben müködnek. A megyei önkormányzat területi önkormányzat, amely törvényben meghatározottak szerint területfejlesztési, vidékfejlesztési, területrendezési, valamint koordinációs feladatokat lát el. A fővárosi önkormányzatot sajátos kettősség jellemzi, mivel egyben települési és területi önkormányzatnak is minősül.

Továbbra is minden településen választanak polgármestert és müködik képviselö-testület.

A törvény megváltoztatta ugyanakkor az önkormányzati hivatalok struktúráját. A 2000 fő lakosságot meg nem haladó községekben föszabályként a közös önkormányzati hivatalok biztosítják a helyi ügyintézést. 2000 fő felett önálló polgármesteri hivatalok müködnek.

Az Mötv. szabályozásából a következő súlyponti elemek emelhetők ki:

- a lakosság önszerveződő közösségeinek támogatása, a település önfenntartó képességének erősítése,

- az állami és önkormányzati feladatok újraszabályozása, az önkormányzati feladatok pontosabb és differenciáltabb meghatározása,

- a polgármester státuszának, feladat- és hatáskörének megerösítése,

- az összeférhetetlenségre vonatkozó szabályok egységesítése, méltatlanság jogintézményének szabályozása

- új feladatfinanszírozási rendszer kialakítása, a müködőképesség fenntartása,

- a közös önkormányzati hivatalok struktúrájának kialakítása,

- a megyei önkormányzatok feladatkörének változása a területfejlesztési, vidékfejlesztési, területrendezési és koordinációs feladatok meghatározásával,

- a törvényességi felügyelet eszközrendszerének kialakítása,

- új alapokra kerültek a helyi önkormányzatok kötelezettségvállalására vonatkozó szabályok, amelyeket az Alaptörvény rendelkezései, valamint részletesen a Magyarország gazdasági stabilitásáról szóló törvény tartalmaznak.

\section{A változások}

A törvény elfogadása után eddig több esetben került sor egyes rendelkezések - nem nagymértékủ - módosítására. Összefoglalóan elmondható, hogy a módosításokat alapvetően az alábbiak indokolták:

- az uniós kötelezettség teljesítése érdekében a Kormány magához vonhatja egyes beruházások megvalósítását (a gyakorlati tapasztalatok alapján kerültek kialakításra a szabályok),

- a vagyonkezelői jog tartalmának pontosítása, vagyonhasznosítás szabályai, 
- az aljegyző kinevezési kötelezettségének enyhítése,

- a közös önkormányzati hivatalok létrehozásához szükséges átmeneti szabályok,

- a polgármesterek új bérezési rendszerének stabil meghatározása,

- az egyes önkormányzati feladatok pontosítása (ágazati törvényekkel összefüggésben),

- törvényességi felügyeleti eszközök pontosítása,

- az önkényuralmi politikai rendszerekhez kötődő nevek tilalma a közterületek elnevezésénél,

- a fövárosi és a kerületi önkormányzatok közötti munkamegosztás finomítása,

- a feladatfinanszírozási rendszerre vonatkozó szabályok pontosítása,

- az összeférhetetlenségi szabályok enyhítése,

- a fővárosi közgyülés döntéshozatali rendszerének változása (a kettős többség alkalmazása), a föpolgármester hatáskörének erősítése (pl. vétójog kiterjesztése).

Az Mötv. hatályosulásának kezdeti tapasztalatai alapvetően kedvezőek. A megőrzött alapértékek, illetve a jól bevált megoldások mellett az új jogintézmények is pozitív fogadtatásra találtak és többségében zökkenőmentesen léptek hatályba és müködnek.

Az önkormányzati társulások átalakítását, valamint 2013. január elsejét követően a közös önkormányzati hivatalok megalakítását a Belügyminisztérium módszertani anyagokkal, intenzív tanácsadási tevékenységgel segítette. A változás nagyságrendjéhez képest viszonylag kevés problémás eset jelentkezett. Több mint ötszázzal (csaknem 30\%) csökkent az önkormányzati hivatalok száma. A megyei önkormányzat szerepe átalakult, az új hatáskörei fokozatosan bővülnek, különösen a területfejlesztés területén.

A főváros önkormányzati rendszerében is egészségesebb munkamegosztás alakult ki a fövárosi és a kerületi önkormányzatok között. A fövárosi közgyűlés összetételének változása lehetővé tette, hogy a kerületi és a fővárosi érdekek harmonizálása a közgyülésben történhessen. A döntéshozatali szabályok változása, valamint a főpolgármester jogosítványainak erősítése további lépést jelentett a fövárosi önkormányzati rendszer megújításának útján. Figyelembe véve az Mötv. jelzett módosításait is - elmondható, hogy alapvető strukturális, illetve koncepcionális változtatásra nincs szükség.

\section{A HELYi ÖNKORMÁNYZATOK ÁLTAL ELLÁTOTT FELADATOK RENDSZERE}

A feladat-telepítés meghatározó elveként az Alaptörvény és az Mötv. is rögzíti, hogy a helyi önkormányzati feladat-és hatáskörök a helyi közügyekhez kötődnek. A törvényi szabályozás szerint a helyi közügyek alapvetően a lakosság közszolgáltatásokkal való ellátásához, valamint a helyi önkormányzás és a lakossággal való együttműködés szervezeti, személyi, és anyagi feltételeinek megteremtéséhez kapcsolhatók. A helyi önkormányzatok által ellátandó feladatnak (helyben intézendő közügynek) az tekintendő, melyet a törvényalkotó annak minősít, illetve amelyet a helyi önkormányzat önként felvállal.

Az Alaptörvény 34. cikk (1) bekezdése egyértelmü követelményként írja elö, hogy helyi önkormányzat részére kötelező feladat-és hatáskört kizárólag törvény állapíthat meg. Ugyancsak e cikk rendelkezik a hatáskör-telepítés másik fontos követelményéröl, nevezetesen arról, hogy a helyi önkormányzat kötelező feladat- és hatásköreinek ellátásához, azokkal arányban álló költségvetési, illetve más vagyoni támogatásra jogosult.

Az Alaptörvényből következő követelmény az egyes települések közötti arányosság biztosítása. 


\section{A KÖTELEZŐ ÖNKORMÁNYZATI FELADAT-ÉS HATÁSKÖRÖK DIFFERENCIÁLT TELEPÍTÉSE, A SZAKMAI SZABÁLYOK MEGHATÁROZÁSÁNAK KÖTELEZETTSÉGE}

A differenciált hatáskör-telepítésnek két dimenziója jelenik meg az Mötv.-ben. Egyrészt a jogalkotó ezt általános követelményként rögzíti, másrészt megjelenik az egyes önkormányzati típusok rendeltetésének meghatározása során is. Hangsúlyozni kell, hogy ezek a rendelkezések elsősorban az ágazati jogalkotás számára nyújtanak kötelező támpontokat az egyes közfeladatok önkormányzati szegmenseinek meghatározásához.

A közfeladatok ellátásában játszott erős önkormányzati szerepvállalás, érdemi kompetenciákkal rendelkező önkormányzati rendszert feltételez, melynek meghatározó elemei a települési önkormányzatok. E helyhatóságok állnak a legközvetlenebb kapcsolatban választópolgáraikkal, ezért a helyben biztosítható közszolgáltatásokat - ide értve az alapvető közigazgatási ügyek intézését is - a települési önkormányzatokhoz indokolt telepíteni.

Nem hagyható azonban figyelmen kívül a magyar önkormányzati rendszer azon sajátossága, hogy minden település rendelkezik a helyi önkormányzás jogával. Minden település választópolgárainak közössége maga rendezheti helyi közügyeit. Ugyanakkor méretnagyságban és teljesítőképességben jelentős különbségek mutatkoznak a helyi önkormányzatok között, figyelemmel arra, hogy hazánkban jelentős számú kis lélekszámú település van, ezért indokolt tekintettel lenni a hatáskör-telepítés során az önkormányzatok teherbíró képességére is. $\mathrm{Az}$ európai gyakorlat is ezt támasztja alá, mert a hasonló elvet alkalmazó (egy település-egy önkormányzat) országok (pl. Franciaország) kiemelt figyelmet fordítanak az eltérő sajátosságokra és alkalmazzák a differenciált hatáskör-telepítés elvét.

Az Mötv. a fenti helyzetet figyelembe véve rögzíti, hogy a községnek, a városnak, a járászszékhely városnak, a megyei jogú városnak, a fővárosnak és kerületeinek, valamint a megyei önkormányzatnak egymástól eltérő feladat- és hatáskörei lehetnek. Lényegében ez teremti meg az alapját a differenciált hatáskör-telepítésnek, melyről az Mötv. 11. \$(2)-(3) bekezdései, amelyek szerint törvény a kötelező feladat- és hatáskör megállapításánál differenciálni köteles, figyelembe véve a feladat- és hatáskör jellegét, a helyi önkormányzatok eltérő adottságait, különösen a gazdasági teljesítőképességet; a lakosságszámot és a közigazgatási terület nagyságát.

Jogszabály a hatáskör telepítésével egyidejüleg meghatározza a feladat- és hatáskörellátáshoz szükséges minimális szakmai, személyi, tárgyi és gazdasági feltételeket.

A korábbi szabályozás ugyan ismerte ezt a jogintézményt, de arról némileg másként rendelkezett. A legjelentősebb különbség, hogy a differenciálásra csak lehetőséget biztosított és a jogalkotóra bízta, hogy azzal él-e, és milyen mértékben. Meggyőződésünk, hogy az önkormányzati rendszer már jelzett válságához az is jelentős mértékben hozzájárult, hogy az ágazatok többsége egyáltalán nem vette figyelembe az önkormányzatok eltérő adottságait, és esetenként ugyanazon közszolgáltatások ellátását várta el a kétszáz lelkes falutól, mint a kétszázezres nagyvárostól.

Az ágazati törvényhozás hatáskör-telepítését segíti a jogalkalmazó azzal is, hogy az Mötv. definíciós jellegü szabályozással meghatározza az egyes önkormányzattípusok feladat-meghatározást megalapozó jellemzőit. A szabályozás részletes tartalmától eltekintünk, de jelezzük, hogy a községi önkormányzatok elsődlegesen a helyi lakosság alapvető létfeltételeit, az ehhez szükséges közszolgáltatások közvetlen igénybevételének lehetőségeit biztosítják. A járásszékhely városok, illetve a városok méretüknél, szerepüknél fogva már alkalmasak arra, hogy nem 
csak a saját lakosságuk számára, hanem a környező települések (vagy az egész járás) lakosságának is minőségi szolgáltatást nyújtsanak. A megyei jogú város azokat a közszolgáltatásokat is biztosítja, melyek saját területén túl a megye egészére, vagy nagy részére kiterjednek.

A megyei önkormányzat szerepe teljesen átalakult, területi önkormányzatként területfejlesztési, vidékfejlesztési, területrendezési, valamint koordinációs feladatokat lát el.

A főváros kétszintü önkormányzati rendszere alapjaiban nem változott. Mind a fővárosi, mind a fővárosi kerületi önkormányzat települési önkormányzat, és alapjogaikat tekintve egyenlők, de feladat- és hatásköreik egymástól eltérnek. Jelentős változás következett be azonban a fóvárosi önkormányzat státuszában, mert az új szabályozás azt is rögzítette, hogy a települési önkormányzati minősége mellett egyben a területi önkormányzat feladat- és hatásköreit is elláthatja. Mindezek mellett azt is hangsúlyozni kell, hogy a „fóvárosi” minőség is generál plusz feladatokat. A fóvárosi és a kerületi önkormányzatok közötti munkamegosztás meghatározásánál nem lehet figyelmen kívül hagyni azt, hogy Budapest egységes város, tehát a fóvárosi és a kerületi önkormányzatok közötti hatáskörök megosztásánál ezt szükséges vezérelvnek tekinteni. Ennek megfelelően az Mötv. elsődlegesen a föváros és a kerületek közötti munkamegosztás alapvető szempontrendszerét rögzítette és a fontosabb feladat-és hatáskörcsoportokat is megosztotta a szereplök között.

\section{Az ÁLLAMIGAZGATÁSI FELADAT- ÉS HATÁSKÖRÖK ELLÁTÁSA}

A helyi önkormányzati szervek a helyi közügyek intézésén túl jelentős szerepet játszanak az államigazgatási feladatok ellátásában, az alapvető közigazgatási szolgáltatások egy részét is a helyhatóságok biztosítják a polgárok számára. E feladat- és hatáskörök nem tekinthetők az önkormányzat sajátjának, lényegében az állam „bízza meg” az önkormányzatot, illetve annak tisztségviselőit, szerveit a hatáskör ellátásával. Azon területekről van szó, melyeken indokolt az országosan egységes, azonos eljárás, nincs helye mérlegelésnek, különbségtételnek, azonban e hatáskörök a polgárok alapvető életviszonyait érintik és gyakoriságuk is megalapozza az önkormányzati szervezetrendszer által történő ellátásukat.

Ennek alapját is az Alaptörvény teremti meg 34. cikkének (3) bekezdésében, mely szerint törvény, vagy törvényi felhatalmazáson alapuló kormányrendelet a polgármester, a megyei képviselő-testület elnöke, valamint a képviselő-testület hivatalának vezetője vagy ügyintézője számára kivételesen államigazgatási feladat-és hatáskört is megállapíthat.

Az Mötv. 18.\$-a értelmében, ha törvény vagy törvényi felhatalmazáson alapuló kormányrendelet a polgármester, a főpolgármester, a megyei közgyülés elnöke, a jegyző, valamint a polgármesteri hivatal és a közös önkormányzati hivatal ügyintézője számára államigazgatási feladatés hatáskört állapít meg, vagy honvédelmi, polgári védelmi, katasztrófa-elhárítási ügyekben az országos államigazgatási feladatok helyi irányításában és végrehajtásában való részvételét rendeli el, az ellátásukhoz szükséges költségvetési támogatást a központi költségvetés biztosítja.

\section{A HELYi ÖNKORMÁNYZATOK ÁLTAL ELLÁTOTT FELADATOK VÁLTOZÁSA 2010 UTÁN, AZ MÖTV. FELADAT-TELEPÍTÉSI ELVEINEK, KÖVETELMÉNYEINEK ÉRVÉNYESÜLÉSE, A VÁRHATÓ VÁLTOZÁSOK}

Különösen jelentős volt a változás az államigazgatási hatósági ügyek intézése tekintetében, melyek egy jelentős része az okmányirodákkal együtt a járási hivatalokhoz került. 
Az átalakulást követően a helyi önkormányzatok képviselő-testülete, a polgármester, a bizottság, a jegyző és a hivatal ügyintézője számára megállapított államigazgatási hatáskörök mintegy 40 \%-kal csökkentek. Már itt utalni szükséges arra, hogy a változás a települések nagy hányadát (különösen a kisebb településeket) jóval kisebb mértékben érintette, mert például okmányirodák csak a kijelölt településeken müködtek.

A korábban tisztán önkormányzatok által nyújtott közszolgáltatások közül az állam szerepvállalása egyes területeken erősödött. Az önkormányzati rendszert 1990-től jellemző megyei intézményfenntartói funkció alapvetően állami feladat lett, így az állam biztosít olyan szakosított egészségügyi és szociális ellátásokat, a melyek korábban alapvetően a nagyobb teljesítőképességü városok, vagy a megyék feladata volt.

Az egészségügyi alapellátás biztosítása önkormányzati feladat maradt. Az Mötv. szabályaiból eredő feladat-ellátási szabadság garantálja, valamint az egészségügyi alapellátásról szóló új törvény rendelkezései alapján is megilleti az önkormányzatot a jog, hogy eldöntse: intézmény fenntartásával, társulásban vagy önálló orvosi tevékenység végzésére feljogosított orvossal kötött feladat-ellátási szerződéssel tesz eleget kötelezettségének.

Az egészségügyi szakellátás biztosításában az önkormányzati szerepvállalás tekintetében jelentős változás történt. A korábbi szabályozás értelmében mind a fekvőbeteg-, mind a járóbetegszakellátás fenntartása és müködtetése, a feltételek biztosítása az önkormányzatok feladata volt. Ma a települési önkormányzatok feladata a szakellátások területén főszabályként a járóbeteg-ellátást biztosító nem integrált rendelőintézetek müködtetése.

Az egészségügy területén eddig bekövetkezett változásokat követően az önkormányzati területet érintően nincs tervben rendszerszintü átalakítás.

A szociális, gyámügyi és gyermekvédelmi területen a gyámhatósági feladatok ellátása legnagyobb részben a járási hivatalokhoz került. Az alanyi jogon járó segélyeket az állam biztosítja a járási hivatal útján, a helyi önkormányzatok által mérlegelésen alapuló települési támogatás nyújtható.

A szociális igazgatásról és szociális ellátásokról szóló 1993. évi III. törvény szabályai szerint a helyi önkormányzatok által nyújtható, mérlegelésen alapuló települési támogatáshoz a központi költségvetés közvetlenül visszaigényelhető forrást nem biztosított. Azon önkormányzatok azonban, melyek a helyi bevételből nem tudnak minden rászorult részére segítséget nyújtani, a Belügyminisztériumtól igényelhetnek támogatást.

A köznevelés reformja magába foglalta az önkormányzati feladatok átalakítását is. Az Mötv. elfogadásával egy időben döntött az országgyülés a nemzeti köznevelésről szóló törvényről. Az új szabályozás átfogó változtatást és megváltozott szemléletet hozott, amely jelentősen átalakította a köznevelési intézményrendszert, annak müködését és a hozzá kapcsolódó feladatokat.

A köznevelési törvény egyik legfontosabb jogalkotói alapelve a köznevelés fogalmának bevezetése. A másik alapelv szerint a köznevelés alapvetően az állam közszolgálati feladata.

A szabályozás átfogó megújítása a korábbinál nagyobb állami szerepvállalást jelent a területen, ezért az Mötv. a helyi önkormányzati feladatok közneveléssel kapcsolatos feladatai között már csak az óvodai ellátást tartalmazza.

Fontos a szemléletbeli különbség hangsúlyozása: korábban a fenntartó önkormányzatok nagyfokú önállósággal rendelkeztek, biztosították az oktatás személyi és tárgyi feltételeit, a törvény keretei között szabadon dönthettek köznevelési intézmény létesítéséről, átszervezéséről, megszüntetéséről, tevékenységi körének módosításáról, költségvetéséről, az intézmény vezetőjének kinevezéséről. Az új köznevelési rendszerben az önkormányzatoknak ebben az értelemben a feladatai megszün- 
tek. A tankerületi központ által fenntartott köznevelési intézmény és a szakképzési centrum feladatainak ellátását szolgáló, települési önkormányzati tulajdonú ingatlan és ingó vagyonra vonatkozóan a tankerületi központot és a szakképzési centrumot ingyenes vagyonkezelöi jog illeti meg mindaddig, amíg a köznevelési közfeladat a tankerületi központ vagy a szakképzési centrum részéről történő ellátása az adott ingatlanban meg nem szünik. A köznevelési intézmény feladatainak ellátását szolgáló ingatlan és ingó vagyont nem idegenítheti el, nem terhelheti meg, bérbe nem adhatja a tankerületi központ, valamint a szakképzési cent-rum ingyenes vagyonkezelői jogának fennállása alatt.

Külön területként megjelölhetők az ún. közüzemi szolgáltatások (hulladékgazdálkodás, kéményseprés, ivóvízellátás, szennyvízkezelés, távhőszolgáltatás). E körben is jelentős változások következtek be, nőtt az állam szerepvállalása, a helyi önkormányzatok jellemzően a közszolgáltatást biztosító szerződések megkötését végzik, de a szolgáltatási díjak megállapítása az önkormányzati szférából az államhoz került. A kommunális szolgáltatások területén új jogintézményként jelent meg, hogy állami szervek biztosítják az egyes közszolgáltatások ideiglenes ellátását, ha a szolgáltató nem tudja vagy nem képes azt átmenetileg biztosítani.

\section{A feladatfinanszírozÁs}

\section{A FELADATFINANSZÍrozÁST MEgALAPOZÓ FELADATÁTRENDEZŐDÉSEK AZ ÁLLAM ÉS ÖNKORMÁNYZATOK KöZÖTT}

A rendszerváltást követően nagy autonómiával rendelkező, ugyanakkor széles felelősségre épülő önkormányzati rendszer alakult ki, amely már ekkor magában hordozott több olyan ellentmondást (pl. az elaprózott településszerkezet és a széles feladatrendszer közötti feszültséget), amely később egyre súlyosbodó müködési zavarokhoz vezetett.

A nagyfokú önállóság ellenére folyamatosan szükült az önkormányzatok mozgástere, a helyi közszolgáltatások biztosítása egyre nagyobb erőfeszítéseket igényelt, a finanszírozás elnehezült a diszfunkcionális elemek egymást erősítő hatására.

A fent vázolt helyzet kialakulásának okait keresve alapvetően három tényező emelhető ki: egyrészt az önkormányzati rendszer belső ellentmondásai, működési zavarai, másrészt a nagy ellátórendszerek reformjának elodázása, elmaradása - az állam szerepvállalásának tisztázatlansága -, harmadrészt a folyamatosan csökkenő állami támogatások mértéke (miközben a kötelezően ellátandó feladatok száma jelentősen megnövekedett).

Az előzőekben leírtak miatt tehát az új önkormányzati törvény előkészítésekor kiemelt cél volt az önkormányzati kötelező feladatok pontos, egyértelmü, differenciált meghatározása, a térségi összefogás kiteljesítése, a választópolgárok érdekeinek és igényeinek megfelelő társulási rendszer kialakítása. A 2013-ban bevezetésre került új önkormányzati rendszer elsődleges célja a települések hatékony és stabil müködésének biztositása a kötelező önkormányzati feladatok ellátása, az azonos színvonalú közszolgáltatások biztositása és a települések fejlődési lehetőségének megteremtése érdekében.

Finanszírozási oldalról egyre égetőbb volt az önkormányzatok pénzügyi-gazdasági helyzetének megszilárdítása, biztosabb, új alapokra helyezése, átlátható és egyben kötöttebb támogatási rendszer kialakítása, az önkormányzatok adósságállományának hatékony kezelése, valamint mindezek érdekében a gazdálkodás ellenőrzésének szigorítása. Az átalakult finanszírozási rendszer a korábbi normatíva alapú elosztás helyett jobban igazodik a települések sajátosságaihoz, tényleges feladataikhoz és a valós kiadásaikhoz, figyelembe véve a jövedelemtermelö-képességüket is. 
A Magyarország helyi önkormányzatairól szóló 2011. évi CLXXXIX. törvény (Mötv.), az új köznevelési törvény és még számos egyéb jogszabály előrevetítette azokat a változásokat, amelyeket az ú,j feladatfinanszírozási rendszer kialakítása során figyelembe kellett venni. Az Mötv. differenciáltabb feladattelepítést tartalmaz az önkormányzatok vonatkozásában és ezt a sarkalatos törvényben rögzített követelményt az ágazati jogszabályokban kell részletesen szabályozni.

A települési önkormányzatok számos feladata 2013-tól közvetlenül az állam útján került biztosításra. Ezt a törekvést tükrözte az államigazgatási feladatok járási hivatalokhoz történő telepítése, vagy az oktatásban az iskolák állami fenntartása, a pedagógusok állami foglalkoztatása.

Az Mötv. szerint a helyi közügyek, illetve a helyben biztosítható közfeladatok 2013-tól a következők:

- településfejlesztés, településrendezés, településüzemeltetés (köztemetők, közvilágítás, kéményseprés, stb.),

- óvodai ellátás,

- szociális, és gyermekjóléti szolgáltatások és ellátások,

- egészségügyi alapellátás (háziorvosi, fogorvos, stb.), az egészséges életmód segítését célzó szolgáltatások, környezet-egészségügy (pl. köztisztaság, rovarirtás),

- kulturális szolgáltatás (könyvtár, közművelődés, előadó-művészet támogatása, stb.),

- helyi környezet- és természetvédelem, vízgazdálkodás, vízkárelhárítás, ivóvízellátás, szennyvízelvezetés, -kezelés és -ártalmatlanítás (csatornaszolgáltatás),

- lakás- és helyiséggazdálkodás,

- honvédelem, polgári védelem, katasztrófavédelem,

- közremüködés a település közbiztonságának biztosításában,

- helyi közfoglalkoztatás,

- helyi adóval, gazdaságszervezéssel és turizmussal kapcsolatos feladatok,

- sport, ifuúsági ügyek,

- nemzetiségi ügyek,

- helyi közösségi közlekedés biztosítása,

- hulladékgazdálkodás,

- távhőszolgáltatás,

- kistermelők, őstermelők jogszabályban meghatározott termékei értékesítési lehetőségének, hétvégi árusításának biztosítása.

\section{A FELADATFINANSZÍrOZÁSI RENDSZER KIALAKÍTÁSÁNAK KERETEI, FÖBB ELVEI}

Az Mötv. 117-118. \$-ai rögzítik a feladatfinanszírozással kapcsolatos alapvetéseket. E szerint a feladatfinanszírozási rendszer keretében az Országgyülés a központi költségvetésről szóló törvényben meghatározott módon a helyi önkormányzatok kötelezően ellátandó, törvényben elöírt egyes feladatainak - felhasználási kötöttséggel - a feladatot meghatározó jogszabályban megjelölt közszolgáltatási szintnek megfelelő ellátását feladatalapú támogatással biztosítja, vagy azok ellátásához a feladat, a helyi szükségletek alapján jellemző mutatószámok, illetve a lakosságszám alapján támogatást biztosít. Egyéb, az elöző feltételnek meg nem felelö feladatokhoz is nyújthat a költségvetés támogatást. 
A támogatás biztosítása a következő szempontok figyelembevételével történik:

- takarékos gazdálkodás,

- a helyi önkormányzat jogszabályon alapuló, elvárható saját bevétele,

- a helyi önkormányzat tényleges saját bevétele.

A figyelembe veendő bevételek körét és mértékét törvény határozza meg, ez a bevétel a költségvetési törvényben rögzítve az iparüzési adóbevétel lett. A módszer, amellyel a saját bevétel figyelembevételre kerül a beszámítás rendszere. A feladatfinanszírozási rendszernek biztosítania kell a helyi önkormányzatok bevételi érdekeltségének fenntartását.

E szabályozási környezetbe kellett illeszteni az újonnan kidolgozandó rendszer alappilléreit. Az Mötv-t., illetve az ágazati jogszabályokat áttanulmányozva először meg kellett határozni azon feladatok körét, amelyet bevétel vagy jövedelemtermelö, illetve „önfenntartó” képessége miatt nem szükséges bevonni a feladatfinanszírozás rendszerébe, hiszen az abból származó bevételek fedezetet biztosítanak a feladat ellátására. Klasszikusan ilyen feladatok a hulladékgazdálkodás, a víz- csatornaszolgáltatás, távhőszolgáltatás vagy a kéményseprés.

Következő lépésben rögzíteni kellett azokat a feladatokat, amelyek valamennyi önkormányzatnál felmerülnek, elöfordulásuk nem esetleges, ellátásukkal kapcsolatban közhiteles adatok állnak rendelkezésre központi szinten.

Ezen feladatok az alábbiak lettek:

- önkormányzati hivatal fenntartása;

- telepuilésüzemeltetési feladatok

o zöldterület gazdálkodás,

o közutak fenntartása,

o köztemetők fenntartása,

o közvilágítás,

- óvodai nevelés,

- szociális és gyermekjóléti feladatok,

- közmúvelődéssel kapcsolatos feladatok.

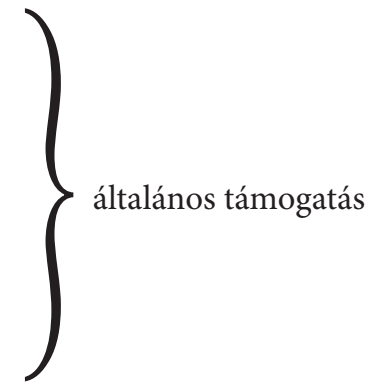

A következő kört azon feladatok képezték, amelyek ellátása nem jellemző valamennyi településre, előfordulásuk esetleges, előre nem becsülhető, illetve jellemző naturális mutatóval, költségelemekkel nem paraméterezhető, így költségvetési modellezése nehezen végrehajtható.

\section{Az általános támogatás elemei}

Az önkormányzat hivatala esetén a finanszírozás a köztisztviselők elismert létszáma alapján történik. Az összege 4580000 Ft/fö. Ennek meghatározása 2011. évi beszámoló adatok alapján történt. Kiszámításra került, hogy mennyi volt az egy köztisztviselőre jutó átlagos bérköltség, illetve átlagos dologi kiadás. A fenti támogatási összegből 3,6 millió forint a bérre eső „rész”, és 980 ezer forint a dologi kiadásokhoz „kapcsolódó” támogatás.

A fajlagos összeg a 2020. évi központi költségvetésröl szóló törvényben 5450000 Ft/fö-re emelkedik.

A közös hivatalok vonatkozásában az Mötv. egyértelmű szabályokat rögzít. Az Mötv. 84-85. \$-ai szabályozzák és tették kötelezővé 2013. január 1-jétől közös önkormányzati hivatal alakítását. E szerint közös önkormányzati hivatalt hoznak létre azon - járáson belüli - községi önkor- 
mányzatok, amelyek területét legfeljebb egy település választja el egymástól és lakosságszámuk nem haladja meg a 2000 főt (de 2000 fö lakosságszámot meghaladó település is tartozhat közös hivatalhoz!). Közös hivatalhoz tartozó települések összlakosságszáma legalább 2000 fö, vagy az ide tartozó települések száma legalább hét kell, hogy legyen.

A közös hivatalokat legkésőbb az Mötv. szabályozásának hatálybalépését (2013. január 1.) követő 60 napon belül, azaz 2013 március 2-áig kellett megalakítani. Ezt követően a létrehozásról vagy megszüntetésről az érintett települési önkormányzatok képviselö-testületei az önkormányzati választások napját követő hatvan napon belül döntenek. Amennyiben a közös hivatalt határidőre nem hozták létre, vagy valamely település nem tudott csatlakozni, akkor a fővárosi és megyei kormányhivatal vezetője jelölte ki az ahhoz tartozó településeket.

A közös hivatalt létrehozó megállapodásban meghatározottak szerint minden érintett településen biztosítani kell az igazgatási munka folyamatos, vagy időszakos ellátásához szükséges személyi és tárgyi feltételeket. Ha a közös önkormányzati hivatalt müködtető települések egyike város, akkor a város a székhelytelepülés, egyéb esetekben a székhelytelepülést a közös önkormányzati hivatalhoz tartozó önkormányzatok képviselö-testületei határozzák meg.

Az elismert hivatali létszám meghatározása különböző paraméterek alapján történt. A végleges döntést megelőzően a minisztérium illetékes főosztálya számos lehetséges feltételt, szempontot mérlegelt. Az elfogadott költségvetési törvény az elismert, finanszírozott létszámot az alábbi paraméterek mellett számítja:

- település közigazgatási státusza,

- közös önkormányzati hivatal esetén a települést alkotó települések száma, együttes lakosságszáma,

- a közös hivatal által kiszolgált nemzetiségi önkormányzatok száma.

Külön kompenzálásra kerültek a járási székhely önkormányzatok sajátos státusza, illetve az építésügyi szolgáltató pont fenntartásáról gondoskodni köteles 5000 fö feletti önkormányzatok 2-2 fö többletlétszámmal.

A kialakított hivatali rendszerrel kapcsolatban 2013 folyamán több észrevétel, kritika fogalmazódott meg az önkormányzatok részéről. A 2014. évi költségvetési törvényben számos „finomítás” már megjelenik: csökkent a kiugró különbség a közel azonos nagyságú községi, illetve városi székhelyü hivatalok között, a finanszírozást kizárólag a közös hivatal székhelye kapja, illetve a székhely települést a rá irányadó beszámításból 5 százalékpontnyi „kedvezmény” illeti meg. Összességében azonban nem változott, hogy a központi költségvetés 25000 köztisztviselő finanszírozására tartalmaz fedezetet.

A településüzemeltetés finanszírozásának kialakítása (zöldterület-gazdálkodás, közút, köztemető, közvilágítás) során a fentiekkel hasonló elvek müködtek, 2014-re vonatkozóan már itt is hasznosításra kerültek az első év tapasztalatai. Az önkormányzatok 2012. évi beszámoló adataiból, meghatározott feladatokhoz köthető szakfeladatok kerültek kiválasztásra, majd meghatározásra kerületek településkategóriánként az egy egységre jutó átlagos nettó müködési kiadások (működési kiadások és működési bevételek különbözete). A naturális mutatók (ha, km, m2) közhiteles nyilvántartásokból, illetve az önkormányzati adatszolgáltatáson alapuló OSAP (Országos Statisztikai Adatgyüjtési Program) adatszolgáltatásból származnak.

Az önkormányzatok az alapvető célkitüzéssel egyetértettek, azonban a nyilvántartások pontatlansága (eddig kisebb figyelmet fordítottak rá az önkormányzatok is, mivel az adatszolgáltatás minőségének eddig anyagi konzekvenciája nem volt), illetve a jelenlegi pénzforgalmi szemléletü 
államháztartási könyvvezetési rendszer számos helyen torzító hatással volt egyes önkormányzatok adataira (pl. forráshiány miatt egy nagyobb összegü közvilágítási számla pénzügyileg nem került rendezésre adott évben, akkor az az önkormányzat beszámoló adataiban sem jelent meg, pedig az adott feladathoz kapcsolódóan ténylegesen felmerült). Az elmúlt évek tapasztalatai azt mutatják, hogy mind az önkormányzatok adatszolgáltatásának, mind könyvelésének minősége sokat javult, így a finanszírozás kiszámításának alapjául szolgáló adatok pontossága egyre nagyobb.

A korábban már hivatkozott beszámítás rendszere a mindenkori éves költségvetési törvényben rögzítettek szerint a települési önkormányzatok müködésének támogatása jogcímeket veszi figyelembe.

Az önkormányzatok finanszírozásában mindig jelen voltak a kiegyenlítés eszközei. Ennek legismertebb formája a 2012. év végéig alkalmazott jövedelemkülönbség mérséklésének rendszere volt, amely az adóerö-képességet vette alapul differenciált formában: nagyon leegyszerüsítve az átlaghoz képest gyengébb jövedelemtermelő-képességgel rendelkező önkormányzatoknak kiegészítést biztosított, míg a jóval átlag feletti jövedelemtermelő képességgel rendelkező önkormányzatoktól elvont. A kiegyenlítés pénzügyi forrását az SZJA átengedett része biztosította (az SZJA átengedés az önkormányzati és állami feladatok átrendeződésével egyidejűleg megszűnt 2013-tól!).

A beszámítás rendszerének alapjai hasonló alapelvekből indultak ki. A beszámítás alapja az önkormányzat elvárt bevétele lett, amely az iparüzési adóalap 0,5\%-a (talán közérhetőbb úgy fogalmazni, hogy amennyiben az önkormányzat a helyi iparüzési adót a maximális $2 \%$-os adókulccsal vette ki, akkor a beszámítás az adóbevételének egy negyedével egyenlö). A rendszerrel kapcsolatos tapasztalatok alapján már 2013 során differenciáltabb lett a rendszer.

\section{Az óvOdAI FELADATOK FINANSZÍROZÁSA}

A köznevelési rendszer átalakításának eredményeként önkormányzati feladat az óvodák fenntartása maradt. Az iskolák tekintetében 2017. év elejétől törvényi rendelkezés alapján mind az oktatási feladatok, mind az iskolaépületek üzemeltetése állami kézbe került.

Az önkormányzatok által foglalkoztatott óvodapedagógusok és az óvodapedagógusok nevelő munkáját közvetlenül segítők bérének és az ehhez kapcsolódó, 19,5\% mértékkel számított szociális hozzájárulási adó kifizetéséhez kapcsolódó támogatás a feladat finanszírozásának egyik eleme. Ezen átlagbér alapú támogatás a szaktörvényben (a nemzeti köznevelésről szóló 2011. évi CXC. törvény) szereplő nevelés-szervezési paraméterek szerint számított pedagóguslétszám, valamint segítói létszám után illeti meg az önkormányzatokat.

Fontos hangsúlyozni, hogy a támogatás megállapításánál - a korábbi szabályozástól eltéröen - fogyatékosságuk típusától függően 2, illetve 3 föként kerülnek figyelembevételre a sajátos nevelési igényü gyermekek.

Az óvodapedagógusok nevelö munkáját közvetlenül segítők létszáma e támogatás igénylése szempontjából a szaktörvény szerint elismerhető - a közalkalmazotti törvény alapján foglalkoztatott - létszám. A szabályozás a segítők létszámában nem ismeri el azon foglalkoztatottakat (gyermek- és ifjúságvédelmi felügyelő vagy gyógypedagógiai asszisztens, a szabadidő-szervező stb.), akiknek az alkalmazása a fenntartó döntésétől függ.

A bértámogatáson túl 97400 forintot igényelhetnek az önkormányzatok gyermekenként az óvodáik működtetéséhez, a jogszabályban foglalt eszközök és felszerelések beszerzéséhez, valamint a feladatellátásra szolgáló épület és annak infrastruktúrája folyamatos müködtetéséhez szükséges kiadásokhoz. 
Az óvodafinanszírozás harmadik eleme a korábbi többcélú kistérségi társulások által kiemelten kezelt feladathoz kapcsolódik: a társulásban fenntartott óvodákba bejáró gyerekek utaztatásának támogatására. Utaztatásuk autóbusz müködtetésével, iskolabusz-szolgáltatás vagy külön célú menetrendszerinti autóbusz szolgáltatás vásárlásával is biztosítható.

Kiegészítő támogatást kapnak az önkormányzatok a pedagógusok és a pedagógus szakképzettséggel rendelkező segítők minősítéséből adódó többletkiadásokhoz.

\section{A gYermekétKeztetés finAnSzírozÁsA}

Az Országgyủlés 2012 novemberében fogadta el az egyes szakosított szociális és gyermekvédelmi szakellátási intézmények állami átvételéről és egyes törvények módosításáról szóló 2012. évi CXCII. törvényt, amely - többek között - megváltoztatta a gyermekétkeztetésre vonatkozó szabályokat.

A módositás értelmében - ha a szülő (törvényes képviselö) eltérően nem rendelkezik - a települési önkormányzatokat kötött felhasználású támogatás illeti meg az általuk a bölcsődében, mini bölcsődében, a fogyatékos személyek nappali intézményében elhelyezett gyermekek számára biztosított, továbbá az óvodai, iskolai, kollégiumi és externátusi gyermekétkeztetés egyes kiadásaihoz.

Az étkeztetés biztosítására kötelezett önkormányzat e feladatának ellátásához a közigazgatási területén kívülről érkező gyermek, tanuló lakóhelye szerinti önkormányzattól hozzájárulást kérhet. Iskolai étkeztetésben részesülhet az a tanuló is, aki a napközit nem veszi igénybe. Az étkezések közül az ebéd külön is igényelhetö.

A települési önkormányzatok fö felelőssége tehát a gyermekek étkeztetésének megszervezése, bölcsődében, óvodában és iskolában egyaránt.

\section{A SZOCIÁlIS FELADATOK FINANSZÍROZÁSA}

A szociális és gyermekjóléti ellátások terén jelentős változások történtek a 2013. évben. Cél, hogy

- rövid távon a feladat-ellátási kötelezettségek újrastrukturálása és a feltételek egyszerüsítése által az ellátórendszer ismert anomáliái megszüntetésre kerüljenek,

- hosszabb távon mindezek eredményeképpen hatékonyabb, gazdaságosabb, racionálisabb intézményrendszer jöjjön létre.

Ennek következtében a 2012-ben önkormányzati fenntartásban levő, fogyatékosokat, pszichiátriai és szenvedélybetegeket ellátó szociális szakosított ellátási, és a tartós bentlakásos gyermekvédelmi szakellátási intézmények 2013. január 1-jétől állami fenntartásba kerülnek.

Az önkormányzatok szerepe az alapellátások területére koncentrálódik, szakellátási (bentlakásos ellátási) felelőssége a jövőben csak az idős és hajléktalan személyekre terjed ki.

A települési önkormányzatoknak a szociális igazgatásról és szociális ellátásokról szóló 1993. évi III. törvényben (a továbbiakban: Szoctv.) rögzített szabályok szerint kell biztosítani a pénzbeli és természetbeni segélyezési ellátásokat.

Fontos ugyanakkor felhívni a figyelmet arra, hogy a járások kialakításáról, valamint egyes ezzel összefüggő törvények módosításáról szóló 2012. évi XCIII. törvény alapján 2013. január 1-jétől egyes segélyezési feladatok - időskorúak járadéka és a hajléktalan személyek részére kifizetett időskorúak járadéka, valamint az alanyi jogú ápolási díj - megállapítása, folyósítása, fenntartása az államhoz került. 
Az önkormányzati segélyezéshez a költségvetési törvény a települési önkormányzatok szociális feladatainak egyéb támogatása jogcímen ad támogatást.

A 2015. év márciusától a segélyezési feladatok zöme az önkormányzatoktól a járásokhoz került. Ennek megfelelően 2015. márciustól a járási hivatalok döntenek:

- a foglalkoztatást helyettesítő támogatásról,

- az időskorúak járadékáról,

- az egészségkárosodási és gyermekfelügyeleti támogatásról,

- alanyi ápolási díjról.

A támogatások folyósítását is a járási hivatal végzi.

A képviselö-testület - a szociális igazgatásról és szociális ellátásról szóló 1993. évi III. törvény (továbbiakban: Szociális törvény) alapján a települési önkormányzat rendeletében meghatározott feltételek szerint - települési támogatást állapíthat meg, mely lehet különösen:

- a lakhatáshoz kapcsolódó rendszeres kiadások viseléséhez,

- a 18 életévét betöltött tartósan beteg hozzátartozójának az ápolását, gondozását végző személy részére,

- a gyógyszer-kiadások viseléséhez,

- a lakhatási kiadásokhoz kapcsolódó hátralékot felhalmozó személyek részére,

- és rendkívüli települési támogatás.

Az önkormányzat a fentieken túl más jogcímeket is létrehozhat a települési támogatás körében. Rendkívüli települési támogatásban elsősorban azokat a személyeket indokolt részesíteni, akik önmaguk, illetve családjuk létfenntartásáról más módon nem tudnak gondoskodni, vagy alkalmanként jelentkező többletkiadások - így különösen betegséghez, halálesethez, elemi kár elhárításához, a válsághelyzetben lévő várandós anya gyermekének megtartásához, iskoláztatáshoz, a gyermek fogadásának előkészítéséhez, a nevelésbe vett gyermek családjával való kapcsolattartásához, a gyermek családba való visszakerülésének elősegítéséhez kapcsolódó kiadások - vagy a gyermek hátrányos helyzete miatt anyagi segítségre szorulnak.

Az új, települési támogatás elnevezésű segélyezési forma révén a települési önkormányzatok a helyi szükségletekre koncentrálva nyújthatnak segítséget lakosaiknak. Ehhez alapvetően a saját forrásaikat tudják felhasználni, amelynek köre 2015. évtől kibővült, az önkormányzatok a jövőben szabadabban adóztathatnak, un. települési adót is kivethetnek.

Az állam a jövőben a költségvetési törvény rendelkezései szerint csak azoknak a településeknek nyújt majd támogatást a települési segélyezési feladatokhoz, amelyek kellő helyi bevételre ennek ellenére sem tudnak szert tenni.

Az alapszolgáltatások körében jelentősebb változás nem történt az önkormányzati feladatellátás esetében, a költségvetési törvény az előző évi szabályokhoz hasonló módon, alapvetően változatlan igénylési feltételek mellett biztosítja a hozzájárulásokat az egyes alapellátásokhoz.

A szakosított ellátás jelentős része - ahogy korábban utaltunk rá - állami feladattá vált 2013tól. A települési önkormányzatokat az általuk fenntartásban maradt - a Szoctv. szabályainak megfelelően müködtetett - időskorúak átmeneti és tartós, valamint a hajléktalanok tartós bentlakást nyújtó intézményeik egyes kiadásaihoz kötött felhasználású támogatásban részesülnek. 
A költségvetés által e célra jutatott előirányzatból a finanszírozás kételemű: az elismert szakmai dolgozók bértámogatásából és az intézmény-üzemeltetési támogatásból áll.

A Gyvt. 2016. évi módosítása átalakította a bölcsődei ellátás rendszerét is. A törvényben meghatározott bölcsődei ellátást biztosító települési önkormányzat az általa fenntartott bölcsődébe, mini bölcsődébe beíratott és ellátott gyermekek után támogatást vehet igénybe, melynek forrása a központi költségvetés IX. fejezete.

\section{A KULTURÁlis FELADATOK FINANSZÍrOZÁSA}

A települési önkormányzatokat a kulturális alapellátás biztosításához, a muzeális intézmények fenntartásához, a nyilvános könyvtári feladatok ellátásához és a közművelődési alapszolgáltatások biztosításához költségvetési támogatás illeti meg.

Külön elöirányzat biztosít támogatást a települési önkormányzatok által fenntartott, illetve támogatott előadó-müvészeti szervezetek támogatására. A támogatás rendszerét az előadó-müvészeti szervezetek támogatásáról és sajátos foglalkoztatási szabályairól szóló 2008. évi XCIX. törvény (Emtv.) határozza meg.

A IX. fejezet biztosítja a fedezetet a 2017. január 1-jétől bevezetett kulturális illetménypótlék fizetésére is.

\section{A HELYI KÖZSZOLGÁltATÁs INFORMÁCIÓS RENDSZER (IKIR)}

A Helyi közszolgáltatás információs rendszer (IKIR) a Belügyminisztérium KÖFOP-2.3.1VEKOP-16-2016-00001 kódszámú kiemelt projektjeként valósult meg, mely 2018. májusától éles rendszerként müködik.

Az IKIR stratégiai célja a települési önkormányzatok által ellátandó helyi közszolgáltatások helyi és állami szintű tervezésének, valamint a helyi szintű operatív feladatellátás megszervezésének és fejlesztésének támogatása. Ennek megfelelöen az IKIR a helyi önkormányzatok hatáskörébe tartozó helyi közszolgáltatásokra fókuszáló vezetői információs és döntés-támogató rendszer.

Az IKIR hatékonyan támogathat a helyi közszolgáltatások kapcsán olyan elemzési, döntéselőkészítő tevékenységeket, amelyeket a települési önkormányzatok és a helyi közszolgáltatások kapcsán érintett ágazatirányítói szintű, központi szervezetek a napi működésük keretében rendszeresen végeznek. Az önkormányzatok esetében ez a helyi közszolgáltatások ellátásának feladatméretezéséhez, a feladatellátási struktúra tervezéséhez, optimalizálásához kapcsolódó igények kiszolgálását jelenti, az érintett ágazatirányítói szintű, központi szervezetek esetében pedig a helyi közszolgáltatások ellátásához kapcsolódó központi koordinációs, felügyeleti, szabályozási és finanszírozási feladatokhoz kapcsolódó információs és elemzési igényeket foglalja magába.

Az IKIR fő szolgáltatásai három kiemelt funkció köré csoportosíthatóak:

- forrásrendszeri adatok elemzését kiszolgáló, támogató funkciók;

- önkormányzati feladatellátás tervezését, elemzését támogató funkciók; valamint

- elégedettség-mérési funkciók. 


\section{A FORRÁSRENDSZERI ADATOK ELEMZÉSÉT KISZOLGÁLÓ, TÁMOGATÓ FUNKCIÓK}

Az IKIR a helyi közszolgáltatások, ezen belül is elsősorban a helyi önkormányzatok által kötelezően, vagy speciális feltétellel kötelezően ellátandó közszolgáltatások feladatellátási struktúrájának elemezhetővé, tervezhetővé, tételét kívánja biztosítani.

Az IKIR-ben megtalálható adatok és információk elsődlegesen központi forrásrendszerekből származnak, melyekbe az önkormányzatok, önkormányzati intézmények, közfeladatot ellátó egyéb intézmények meglévő adatszolgáltatási kötelezettségei alapján jelenleg is adatot szolgáltatnak. Az adatok rendszeres időközönként történő átadás-átvételére forrásrendszerenkénti megállapodások és protokollok kerültek kialakításra, ezáltal az önkormányzatoknak új adatszolgáltatási kötelezettsége az IKIR irányába nem keletkezik.

Az IKIR mint vezetői információs és döntés-támogató rendszer a felhasználói lekérdezéseket a szakrendszeri adatszolgáltatások közszolgáltatásokat érintő adatainak strukturált elemzéseivel és lekérdező funkciók segítségével szolgálja ki.

A fentiekhez önálló folyamatok szabályozzák az adatok ellenőrzését és betöltését. A forrásrendszerekből történő adatátvétel történhet online (interface-en keresztüli automatikus átvétel, vagy web-es felületen tárolt helyről történő átvétel) és offline (adathordozón történő átvétel) módon.

Az IKIR felhasználói az IKIR elemző modulja segítségével előre meghatározott adatszerkezetü riportokat kérdezhetnek le, vagy egyedileg összeállított adatszerkezetű riportokat generálhatnak, azokon összetett elemzéseket végezhetnek a forrásrendszerektől átvett adatokra építve, figyelembe véve akár a hasonló települési adottságokkal rendelkező települések kiválasztása útján elérhető nyilvános információkat is.

1. Állandó lakosság - kor és nemek megoszlása

Budapest mutatói idōsorosan $\quad$ Felhasználó: MUSTER ERIK

\begin{tabular}{|c|c|c|c|c|c|c|}
\hline & & & & Év & & : \\
\hline Mutató & : & 2015. & 2016. & 2017. & 2018. & 2019. \\
\hline Állandó lakosok száma [fó] (SZL) & & 1704649 & 1705272 & 1697367 & 1693051 & 1686361 \\
\hline Állandó lakosságból a 0-2 évesek száma [fố] (SZL) & & 47876 & 47483 & 47387 & 46302 & 44859 \\
\hline Állandó lakosságból a 3-5 évesek száma [fó] (SZL) & & 48090 & 47573 & 46683 & 46487 & 45552 \\
\hline Állandó lakosságból a 6-13 évesek száma [fố] (SZL) & & 117897 & 120852 & 122356 & 123388 & 123859 \\
\hline Állandó lakosságból a 14 évesek száma [fō] (SZL) & & 12990 & 13266 & 13572 & 13531 & 13943 \\
\hline Állandó lakosságból a 15-17 évesek száma [fố] (SZL) & & 38054 & 38183 & 38798 & 39721 & 40266 \\
\hline Állandó lakosságból a 18-59 évesek száma [fō] (SZL) & & 975649 & 968593 & 958783 & 955705 & 952389 \\
\hline Állandó lakosságból a 60-x évesek száma [fô] (SZL) & & 464093 & 469322 & 469788 & 467917 & 465493 \\
\hline
\end{tabular}

A riport a Belügyminisztérium (BM) 'Személyiadat- és lakcímnyilvántartásának' (SZL) azon föbb demográfiai adatait tartalmazza, melyekböl kiolvashatók az állandó lakosság kor- és nemek szerinti változása, valamint az ezekre hatással lévố egyéb népességi mutatószámok.

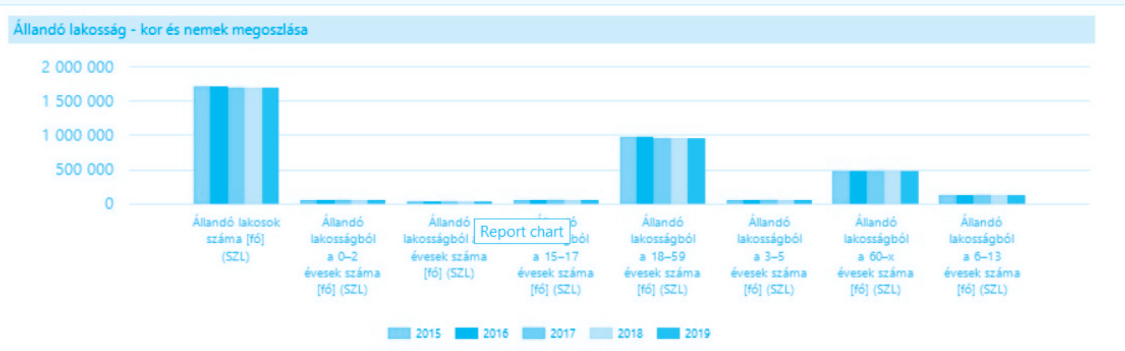


További, a felhasználó által személyre szabható lehetőség az elemzéshez kapcsolódó gyors információ elérésben az információs pult és annak kezelése, mely egy felületen tud megmutatni minden olyan adott települési információt, amelyek az adott felhasználó számára a legfontosabbak és az IKIR adattárházából kinyerhetők. Az elemek megjelenítésénél fontos a vizualitás, hiszen az ennek a felületnek a szerepe egy nagyon gyors és intenzív információ átadás.

\section{Az ÖNKORMÁNYZATI FELADATELLÁTÁS TERVEZÉSÉT, ELEMZÉSÉT TÁMOGATÓ FUNKCIÓK}

Az IKIR önálló modulban lehetőséget biztosít az önkormányzatok számára a közszolgáltatási feladatellátási sturktúrájuk rendszerben történő leképezésére és komplex elemzésére, a tervváltozatok összevetésére, illetve az egyes forgatókönyvek szimulációjára. Tekintettel arra, hogy a rögzített adatok a helyi szintü vezetői döntés-elökészítést szolgálják, azokat alapesetben csak a tervezést végző önkormányzat tekintheti meg, de lehetősége van saját döntése alapján elérhetővé tenni azokat más önkormányzati (pl. társulásban lévő másik önkormányzat) felhasználók számára is. A forrásrendszerből nyert adatok mellett az önkormányzatoknak lehetősége van az önkormányzati alapadatok IKIR-be történő feltöltésére és folyamatos karbantartására is.

MUTATÓK
BEVÉTELEK

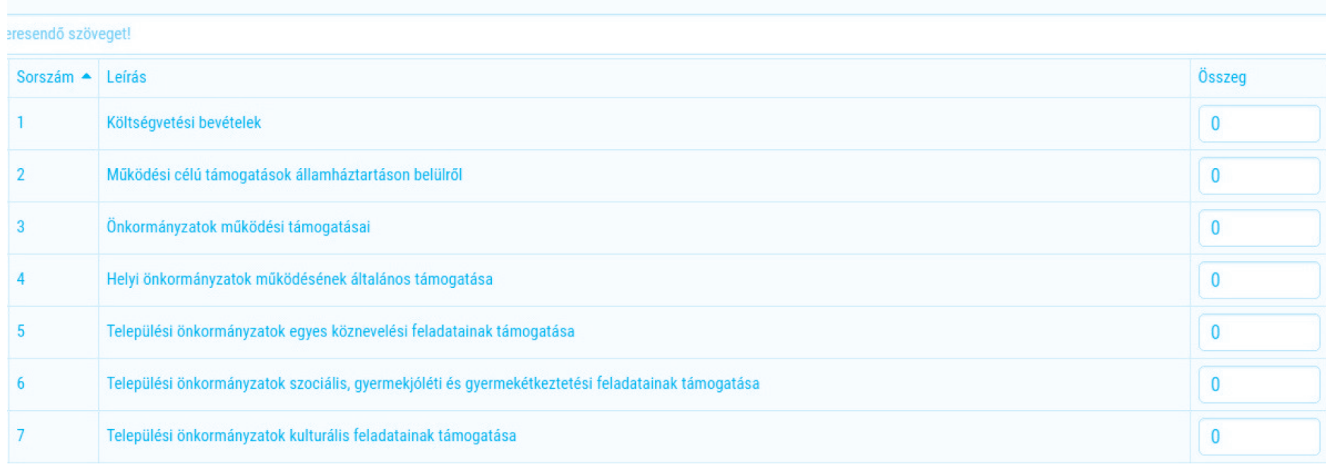

A funkció használatának első része a kijelölt közszolgáltatásra vonatkozó helyi feladatellátási struktúra (intézmények és közfeladat ellátási helyek viszonyának) definiálása.

Ezt követően a funkció használatával lehetővé válik az önkormányzatok számára:

- a jelenlegi feladatellátási struktúra elemzése,

- a rendszerbe bevitt tervek összehasonlítása, összehasonlító elemzések elvégzése, valamint

- a feladatellátási struktúra módosítása, optimalizációja, az ellátás módjára vonatkozó alternatívák képzése, modellezése. 


\section{AZ ELÉGEDETTSÉGMÉRÉSI FUNKCIÓK}

Az IKIR elégedettségmérési funkciója használatával minta kérdés- és kérdőívbankra támaszkodva az önkormányzati felhasználók kérdőíveket állíthatnak össze a közszolgáltatások minőségével kapcsolatos vélemények felmérése céljából. A funkció használatáról és az összeállított kérdőív tartalmáról az önkormányzatok dönthetnek a helyi közszolgáltatási hangsúlyok ismeretében. A települési közszolgáltatásra vonatkozó elégedettségmérési eredmények csak az érintett település számára lesznek elérhetőek.

Az elégedettségmérés eredményeinek feldolgozásával egyértelmü képet kaphatnak az önkormányzatok és a közszolgáltatás teljesítésében közreműködők arról, hogy az közszolgáltatásokat igénybe vevő állampolgárok, szervezetek milyen véleményt és elvárásrendszert alakítottak ki az igénybevett közszolgáltatások minőségével, elérhetőségével, igénybevételével kapcsolatban.

Általános elégedettségi kérdések

Általános elégedettség a bölcsổdei ellátással kapcsolatban

Válasz

$\bigcirc_{1} \bigcirc_{2} \bigcirc \bigcirc_{3} \bigcirc{ }_{4} \bigcirc 5$ Nem minösitem vagy nincs véleményem $\bigcirc$ Nincs ilyen vagy nem tudok róla

Konkrét elégedettségi kérdések

A bölcsōdei csoportszoba célnak való megfelelôsége

Válasz

$\bigcirc_{1} \bigcirc_{2} \bigcirc \bigcirc_{3} \bigcirc_{4} \bigcirc 5$ Nem minösitem vagy nincs véleményem $\bigcirc$ Nincs ilyen vagy nem tudok róla

A kisgyermeknevelők hozzáállása

Válasz

$\bigcirc_{2} \bigcirc 3 \bigcirc 4 \bigcirc 5$ Nem minôsitem vagy nincs véleményem $\bigcirc$ Nincs ilyen vagy nem tudok róla

A kisgyermeknevelők munkáját közvetlenül segítô személyek hozzáállása

Válas:

${ }_{1} \bigcirc{ }_{2} \bigcirc{ }_{3} \bigcirc 4 \bigcirc 5$ Nem minösitem vagy nincs véleményem $\bigcirc$ Nincs ilyen vagy nem tudok róla

A bölcsóde nyitvatartási ideje

Válasz

$\bigcirc_{1} \bigcirc_{2} \bigcirc_{3} \bigcirc_{4} \bigcirc 5$ Nem minösitem vagy nincs véleményem $\bigcirc$ Nincs ilyen vagy nem tudok róla

A kisgyermeknevelōk szülökkel való kapcsolattartása

Válasz

$\bigcirc 1 \bigcirc 2 \bigcirc \bigcirc_{3} \bigcirc{ }_{4} \bigcirc 5 \bigcirc$ Nem minösitem vagy nincs véleményem $\bigcirc$ Nincs ilyen vagy nem tudok róla

A rendszer elemzi a beérkezett válaszokat és megjelöli a kiugró értékeket, ezáltal támogatja az adattisztítási és adatelemzési tevékenységeket. Az önkormányzatok részletesen elemezhetik a beérkezett elégedettségmérési eredményeket, az IKIR adattárába publikált eredmények elemzési 
lehetőségei pedig bővithetőek az egyéb forrásrendszerből származó közszolgáltatást érintő adatok összevetéssel. Az önkormányzati felhasználó az ügyfelek (lakosság, vállalkozások stb.) által adott válaszokból mutatókat állíthat elő az elégedettségi adatok IKIR forrásrendszeri adatokkal való együtt-elemezhetősége érdekében.

Az IKIR segítségével az adatfelvétel (adatbegyüjtés) online módon (vagy akár papír alapon) is megtörténhet, valamint a felmérés státusza (kitöltési arány) is folyamatosan követhetö. Az elégedettségmérési adatokat csak a felmérést végző helyi önkormányzatok munkatársai láthatják, de az önkormányzatok által publikálhatók, azaz a „gazda” önkormányzat szándékainak megfelelően tetszés szerint megoszthatók más önkormányzatokkal.

\section{Az IKIR-HEZ VALÓ HOZZÁFÉRÉS}

Az IKIR felhasználói körét az önkormányzatok és a központi igazgatás szereplői teszik ki, számukra készült el maga a rendszer. Jelenleg közel 1300 önkormányzat és több mint 1700 regisztrálója van a rendszernek. Ez különösen nagy eredmény annak tekintetében, hogy az önkormányzatok IKIR rendszerhez csatlakozása önkéntes alapon történik.

Az egyes felhasználók, a szerepkörükhöz rendelt jogosultságok alapján különbözö IKIR funkciókat érhetnek el. Önkormányzati és központi szinten - adatérzékenységi szempontok miatt egyaránt kétszintü jogosultságkezelés érvényesül: az önkormányzatok esetében a (fö)polgármester és a (fö)jegyző, mint kiemelt felhasználó, a teljes IKIR portálfunkcionalitáshoz hozzáférhet, és további hozzáférési jogosultságokat oszthat ki szakterületi kollégák, mint felhasználók részére.

\section{Az IKIR KÖZPONTI SZAKMAI KARBANTARTÁSI, FELHASZNÁLÓ TÁMOGATÁSI ÉS MÜKÖDTETÉSI FOLYAMATAI}

Az IKIR rendszer közvetlenül biztosít adathozzáférési és elemzési lehetőséget az önkormányzat által arra feljogosított felhasználó számára, ugyanakkor összetettebb elemzések elkészítését a Belügyminisztérium szervezetén belül létrehozott IKIR szakmai támogató, kompetencia központ is segíti. Ez a szervezet felelös az IKIR napi szintű szakmai, operatív müködtetéséért, a korábban említett adatintegrációs folyamatokért, valamint segítséget nyújt a felhasználók regisztrációjában, és a felhasználók támogatásában is. 